\title{
Familial infantile gigantism
}

INSERM

\section{Source}

INSERM. (1999). Orphanet: an online rare disease and orphan drug data base. Familial infantile gigantism. ORPHA:300373

Familial infantile gigantism is a rare, genetic, endocrine disease characterized by earlyonset (before the age of five years old) excessive acceleration of linear growth and body size (height Z-score >4.5 SD) due to pituitary mixed growth hormone- and prolactinsecreting adenomas and/or mixed-cell pituitary hyperplasia. Patients present gigantism and may associate acromegalic features (e.g. coarse facial features, frontal bossing, prognathism, increased interdental space) as well as marked enlargement of hands and feet, soft tissue swelling, appetite increase and acanthosis nigricans. 